\title{
Bioguided study of the Antarctic alga Himantothallus grandifolius (A. Geep \& E.S.Geep) indicates 13E-Docosenamide as potential antileishmanial agent
}

Leandro Costa Clementino ${ }^{1,2}$, Fabio Aurelio Esteves Torres ${ }^{1}$, Angela Maria Arenas Velasquez ${ }^{2}$, Leonardo Villela ${ }^{3}$, Toyota Fujii Mutue ${ }^{4}$, Pio Colepicolo ${ }^{3}$, Marcia A. S. Graminha ${ }^{2 *}$

${ }^{1}$ São Paulo State University (UNESP), Chemistry Institute, Araraquara 14.800-900, Brazil.

${ }^{2}$ School of Pharmaceutical Sciences, São Paulo State University (UNESP), Araraquara 14.800-903, Brazil.

${ }^{3}$ Chemistry Institute, University of São Paulo (USP), São Paulo 05513-970, Brazil.

${ }^{4}$ Institute of Botany (IBt), São Paulo, 01061-970, Brazil.

\begin{tabular}{|c|c|}
\hline ARTICLE INFO & ABSTRACT \\
\hline $\begin{array}{l}\text { Received on: } 21 / 05 / 2020 \\
\text { Accepted on: } 23 / 09 / 2020 \\
\text { Available online: } 05 / 12 / 2020\end{array}$ & $\begin{array}{l}\text { Constant efforts to discover new antileishmanial agents are important because there are only a few available drugs } \\
\text { for the treatment of leishmaniasis, which present several drawbacks including high toxicity and difficult route of } \\
\text { administration. In this scenario, different sources of natural products have been explored regarding their potential } \\
\text { to treat infectious diseases. Following this initiative, our research team has been analyzing the bioactive potential }\end{array}$ \\
\hline $\begin{array}{l}\text { Key words: } \\
\text { 13E-docosenamide, } \\
\text { desmarestiaceae, antarctic } \\
\text { macroalgae, fatty acid, } \\
\text { antileishmanial activity. }\end{array}$ & $\begin{array}{l}\text { of Himantothallus grandifolius, an endemic macroalga of the Antarctic region, with the hypothesis that the hostile } \\
\text { environment imposed on these organisms has shaped its arsenal of chemical constituents, thus consequently bringing } \\
\text { new opportunities to discover bioactive compounds that might be useful against leishmaniasis. Herein, we report the } \\
\text { antileishmanial property of the fatty acid 13E-docosenamide, identified during the fractionation of the hexanic extract } \\
\text { of } H \text {. grandifolius after semipreparative high performance liquid chromatography separation and ultrafast liquid } \\
\text { chromatography coupled with mass spectrometry analyses to track its antileishmanial constituents. } 13 \mathrm{E}-\text { docosenamide } \\
\text { was found in HSG11and HSG12 fractions, presented promising antileishmanial activity }\left(\mathrm{IC}_{50}=9.6 \mu \mathrm{gl}^{-1}\right) \text { and is } 10 \\
\text { times more selective to the parasite rather than to the host cells (SI }>10.4) \text {. }\end{array}$ \\
\hline
\end{tabular}

\section{INTRODUCTION}

The food industries consume a wide range of algae, which are well known to have high contents of polysaccharides, fatty acids, sterols, fiber, minerals, vitamins, and a large number of antioxidants (Gambato et al., 2014; Pereira et al., 2012). Currently, the bioproducts isolated from the algae are promising and present great potential for the discovery of new therapeutic compounds. Although several natural products obtained from marine macroalgae have been identified and bioactively

"Corresponding Author

Marcia A S Graminha, São Paulo State University (UNESP), School of Pharmaceutical Sciences, Araraquara, Brazil.

E-mail:marcia.graminha@unesp.br characterized, only a small number have been explored regarding their potential to produce antileishmanial agents (Cardozo et al., 2007; Torres et al., 2014). Himantothallus grandifolius (A and E Gepp) is a brown alga found in the Antarctic islands and sub-Antarctic regions; this macroalga is a member of the order Desmarestiales in the Phaeophyceae class and can reach a length of $17.5 \mathrm{~m}$ (Dieckmann et al., 1985; Drew and Hastings, 1992). This alga occurs in the Antarctic and sub-Antarctic regions, being found at a depth of $30-100 \mathrm{~m}$ in the Admiralty Bay, South Shetlands Islands (Dieckmann et al., 1985). Considering that this macroalga belongs to the same class as Sargassum, an edible alga, it is reasonable to suppose its potential commercial value (Gambato et al., 2014). Studies regarding the bioactivity potential of $H$. grandifolius have been poorly investigated and it is restricted to a single record describing an anticancer activity associated with phlorotannins ( Gambato et al., 2014; Iken et al., 2007). This work 
investigates the potential of $H$. grandifolius secondary metabolites against leishmaniasis. This parasitic disease endangers more than one billion people in endemic areas throughout the world and if left untreated it can lead to 20,000-30,000 deaths annually (Molyneux et al., 2016). Currently, there are few therapeutic options for the treatment of leishmaniasis including pentavalent antimony, amphotericin B, miltefosine, and paromomycin, which present several drawbacks such as high toxicity and low efficacy (Sundar and Chakravarty, 2015), which makes the discovery of new therapeutic alternatives urgent. Therefore, the aim of this study was to evaluate the antileishmanial activity of extracts and fractions of the Antarctic alga H. grandifolius against Leishmania amazonensis, the etiologic agent of cutaneous leishmaniasis, followed by UPLC-MS analyses revealing for the first time the antileishmanial properties of $13 \mathrm{E}$-docosenamide.

\section{MATERIALS AND METHODS}

\section{Reagent and chemicals}

Hexane and ethanol were purchased from Merck. Acetonitrile and isopropanol, ultrafast liquid chromatography (UFLC) coupled with mass spectrometry high performance liquid chromatography (HPLC) grade, were obtained from J.T. Baker, while 13E-docosenamide (chemical abstracts service number: 112-84-5), penicillin/streptomycin, MTT (3-4(4,5-dimethyl-2thiazolyl)-2,5-diphenyl-2H-tetrazolium bromide), phenazine methosulfate (PMS), and dimethyl sulfoxide (DMSO) were obtained from Sigma-Aldrich. The reference drug amphotericin B was purchased from Cristalia.

\section{Plant material}

Samples of $H$. grandifolius were collected in Punta Plaza, King George Island, Antarctic Ocean, in January $2012\left(62^{\circ} 5^{\prime} \times\right.$ $58^{\circ} 24^{\prime}$ ). The alga was identified by Dr. Toyota FujiiMutue in the laboratory of the Brazilian Antarctic base "Comandante Ferraz" (Gambato et al., 2014). The collected macroalgae were dried at room temperature, placed in a plastic bag, and kept at $-80^{\circ} \mathrm{C}$ until use.

\section{Extraction and fractionation procedure}

The macroalgal specimen was freeze-dried and powdered. The algal powder was inserted in cellulose cartridges and maintained for 14 hours submerged in hexane and ethanol $(1: 10, m / v)$, followed by Soxhlet extraction for 4 hours. The extracts were dried in a rotary evaporator (Punín Crespo and Lage Yusty, 2006). For the hexanic extract fractionation, we used the semipreparative HPLC UV-PDA detector, with a Shimadzu LC6AD pump, communication module 20-A, and a detector SPDM10AVP with FRC-10A fraction collector. The HPLC output was scanned from 210-800 nm with a column Shim-Pack $5 \mu \mathrm{m} \mathrm{C18}$, $250 \times 4.6 \mathrm{~mm}$ column (Shimadzu). The mobile phase A consisted of $1 \%$ formic acid and solution B consisted of acetonitrile : isopropanol (50:50). Separations were made by a gradient elution program as follows: $0-2$ minutes $(60 \% \mathrm{~B}), 2-20$ minutes $(60 \%-$ $90 \%$ B), 20-30 minutes (90\% B), 30-30.1 minutes (60\% B), and $30.1-40$ minutes $(60 \% \mathrm{~B})$ at a flow rate of $1 \mathrm{ml}$ minute ${ }^{-1}$ and injection volume of $5 \mu \mathrm{l}$.

\section{Ultrafast liquid chromatography coupled with mass spectrometry (UFLC-MS) analyses}

UFLC was carried out using a UFLC system (Shimadzu, USA) consisting of a solvent delivery pump (Model LC-20AD) and autosampler (SIL-20Aht) with a $100 \mu$ loop, degasser (DGU 20A3r), and column oven (CTO-20A). This system was coupled to a Bruker ESI-microTOF II mass spectrometer. System operation was carried out using tof-Control and HyStar V.3.2, while data collection and analysis were carried out using Compass Data Analysis V.4.1. Gradient elution for the hexane extract of $H$. grandifolius was carried out on a Phenomenex ${ }^{\circledR}$ Kinetex C18 column $(50 \times 2.1 \mathrm{~mm}, 2.6 \mu \mathrm{m})$ at $30^{\circ} \mathrm{C}$. Mobile phase A consisted of $1 \%$ formic acid and solution B consisted of acetonitrile : isopropanol (50:50). Separations were made by a gradient elution program as follows: $0-2$ minutes $(10 \%$ B), 2-20 minutes $(10 \%-75 \% \mathrm{~B})$, and $20-25$ minutes $(75 \% \mathrm{~B})$, at a flow rate of $500 \mu \mathrm{l} /$ minutes and the injection volume was $5 \mu \mathrm{l}$. Mass detection was carried out for scanning the $\mathrm{m} / \mathrm{z}$ between 50 and 1,100 in a positive mode with the following parameters: 4,500 $\mathrm{V}$, endplate offset $-500 \mathrm{~V}$, nebulizer $2.0 \mathrm{Bar}$, dry heater $200^{\circ} \mathrm{C}$, and dry gas flow at a flow of 91 minutes $^{-1}$.

\section{Metabolite databases}

Putative identification of metabolites according to the fragmentation standard obtained was carried out using the following databases: Metlin (metlin.scripps.edu/index.php), PubChem (pubchem.ncbi.nlm.nih.gov), CHEBI (www.ebi.ac.uk/ chebi), and ChemSpider (http://www.chemspider.com). Data were accessed in August 2014.

\section{Parasites and macrophage cultures}

Promastigotes of L. amazonensis strain MPRO/BR/1972/ M1841-LV-79 were maintained at $28^{\circ} \mathrm{C}$ in a liver infusion tryptose medium supplemented with $10 \%$ heat-inactivated fetal bovine serum (FBS) until the logarithmic growth phase (3-4 days). Peritoneal macrophages were obtained as previously described (Velásquez et al., 2016). Briefly, cells were collected from the peritoneal cavity of 6- to 8-week-old male Swiss mice, previously stimulated with 3\% thioglycolate. For this, phosphate saline buffer (PBS) ( $\mathrm{pH} 7.4$ ) was injected into the peritoneal cavity, followed by a slight massage, and the content was collected using a syringe (5 $\mathrm{ml}$ ). The cells were then counted and seeded into 96-well plates at a density of $5 \times 10^{5}$ macrophages/ml $(100 \mu 1$ per well $)$ in Roswell Park Memorial Institute (RPMI) 1,640 medium supplemented with 10\% heat-inactivated FBS, $25 \mathrm{mM} \mathrm{N}$-(2-Hydroxyethyl) piperazine- $\mathrm{N}^{\prime}$-(2-ethanesulfonic acid), $2 \mathrm{mM}$ L-glutamine, and $1 \%$ penicillin/streptomycin and incubated for 6 hours at $37^{\circ} \mathrm{C}$ in a $5 \% \mathrm{CO}_{2}$-air mixture for cell adhesion.

\section{Antipromastigote activity}

To determine the half-maximal inhibitory concentration $\left(\mathrm{IC}_{50}\right)$, we carried out a colorimetric assay based on MTT as previously described (Velásquez et al., 2016), with modifications. Briefly, promastigotes were plated in 96-well plates at a density of $1 \times 10^{7}$ parasites $\mathrm{ml}^{-1}$ to a final volume of $100 \mu \mathrm{l}$ and incubated at $28^{\circ} \mathrm{C}$ in the presence of increasing concentrations of $H$. grandifolius 
extracts $\left(7.8-500 \mu \mathrm{g} \mathrm{ml}^{-1}\right.$ ) or fractions (from 3.9 to $250 \mu \mathrm{g} \mathrm{ml}^{-1}$ ) dissolved in dimethyl sulfoxide (DMSO; the highest concentration was $1.4 \%$, which was not hazardous to the parasites, as assessed previously) and incubated at $28^{\circ} \mathrm{C}$ for 72 hours. Then, $10 \mu \mathrm{l}$ of an MTT-PMS solution (6 mM MTT; $0.7 \mathrm{mM}$ PMS) was added to each well, followed by incubation for 75 minutes as described previously. For solubilization of the formazan crystals, they were added to a solution of $10 \% \mathrm{SDS} / 1 \mathrm{M} \mathrm{HCl}$, followed by another incubation for 30 minutes at room temperature and the absorbance was read in a microplate reader at $570 \mathrm{~nm}$. Amphotericin B and untreated parasites were used as positive and negative controls, respectively. Additionally, a medium containing test extract/fraction/compound was also prepared in order to avoid any possible interference caused by the potential reducing capacity of the tested samples, which could increase the absorbance. The $\mathrm{IC}_{50}$ promastigote was determined using nonlinear regression on Bioestat ${ }^{\mathbb{B}}$ software. The assays were carried out in experimental triplicate and biological duplicates, and results were expressed as mean \pm standard deviation.

\section{Evaluation of cytotoxicity on peritoneal macrophages}

The cytotoxicity of the $H$. grandifolius extracts, fractions, and 13E-docosenamide toward murine macrophages was determined in concordance with the protocol approved by the Institutional Ethics Committee, protocol CEUA/FCF/CAr no. $42 / 2016$. In summary, cells $\left(5 \times 10^{5}\right.$ cells $\left.\mathrm{ml}^{-1}\right)$ were incubated in RPMI 1,640 medium, containing decreasing concentrations of extracts/fractions (according to that mentioned in the previous section) and 13E-docosenamide $\left(1.5-100 \mu \mathrm{g} \mathrm{ml} \mathrm{m}^{-1}\right)$, at a final volume of $100 \mu \mathrm{l}$ per well, for 24 hours at $37^{\circ} \mathrm{C}$ in a $5 \% \mathrm{CO}_{2}$-air. Their viability was measured by the MTT colorimetric assay with some modifications. Briefly, after incubation as described earlier, the supernatant was removed and $100 \mu \mathrm{l}$ of ethanol and $100 \mu \mathrm{l}$ of PBS : isopropanol (v/v) were added. The absorbance was read on a spectrophotometer at $570 \mathrm{~nm}$. The cytotoxic concentration of compounds that resulted in $50 \%$ of cell growth inhibition $\left(\mathrm{CC}_{50}\right)$ was determined using nonlinear regression on Bioestat ${ }^{\mathbb{B}}$ software.
The assays were carried out in experimental triplicate biological duplicate and results expressed as mean \pm standard deviation.

\section{Antiamastigote activity}

To evaluate the antileishmanial activity of extracts/ fraction and 13E-docosenamide against L. amazonensis intracellular amastigotes, we used the following methodology (Velásquez et al., 2016). Murine peritoneal macrophages in RPMI 1,640 were seeded at a density of $5 \times 10^{5}$ cells $\mathrm{ml}^{-1}$ (300 $\mu \mathrm{l}$ final volume) containing coverslips of $13 \mathrm{~mm}$ in diameter arranged in a 24 -well plate. After 6 hours of incubation at $37^{\circ} \mathrm{C}$ and $5 \%$ $\mathrm{CO}_{2}$-air mixture for macrophage adhesion, promastigote forms of L. amazonensis at the stationary growth phase (6-7 days) were added to the wells in a ratio of 10:1 (promastigotes:macrophages) and incubated for another 8 hours to allow parasite internalization. After incubation, the medium was replaced, noninternalized parasites were removed by PBS washing, and a new medium was added containing $250-15,62 \mu \mathrm{g} \mathrm{ml}^{-1}$ to extracts/fractions, $100-1,25 \mu \mathrm{mol} \mathrm{l}^{-1}$ to amphotericin $\mathrm{B}$, and 33.7-2.1 $\mu \mathrm{g} \mathrm{ml}^{-1}$ to $13 \mathrm{E}$-docosenamide and plates were incubated for 24 hours at $37^{\circ} \mathrm{C}$ and 5\% $\mathrm{CO}_{2}$-air mixture. Infected macrophages were used as a negative control and amphotericin $\mathrm{B}$ as a positive control.

After incubation, cells were fixed with methanol and Giemsa was stained. The concentration for $50 \%$ inhibition of amastigotes ( $\mathrm{IC}_{50}$ amastigote) was obtained by counting of 100 macrophages in two independent experiments. The values were obtained by nonlinear regression on Bioestat ${ }^{\mathbb{B}}$ software, and results were expressed as mean \pm standard deviation. Additionally, the ratio of antiamastigote activity to host cell toxicity, the selective index $\left(\mathrm{SI}=\mathrm{CC}_{50 \text { macrophages }} / \mathrm{IC}_{50 \text { amastigote }}\right)$ was determined. The infection index was determined according to Clementino et al. (2018) study. Statistical significant differences between treatments using 13E-docosenamide and control (untreated cells) were determined using "a one-way analysis" of variance, by Tukey's multiple comparison test (GraphPad Prism software). $p$-values $<0.05$ (mean $95 \%$ confidence interval) were considered statistically significant.

Table 1. Antileishmanial and cytotoxic activities of extracts and fractions of $H$. grandifolius, 13E-docosenamide, and amphotericin B against L. amazonensis promastigotes/amastigotes and macrophages.

\begin{tabular}{|c|c|c|c|c|c|c|}
\hline \multirow{2}{*}{ Sample } & \multirow{2}{*}{$\begin{array}{c}\text { Fraction } \\
\text { [Himantothallus grandifollius (HGS)] }\end{array}$} & \multirow{2}{*}{$\begin{array}{l}\text { Promastigote } \\
\mathrm{IC}_{50}\left(\mu \mathrm{g} \mathrm{ml}^{-1}\right)\end{array}$} & \multirow{2}{*}{ SI promastigote } & \multirow{2}{*}{$\begin{array}{c}\text { Amastigote } \\
\mathrm{IC}_{50}\left(\mu \mathrm{g} \mathrm{ml}^{-1}\right)\end{array}$} & \multirow{2}{*}{ SI amastigote } & \multirow{2}{*}{$\begin{array}{l}\text { Macrophages } \\
\mathrm{CC}_{50}\left(\mu \mathrm{g} \mathrm{ml}^{-1}\right)\end{array}$} \\
\hline & & & & & & \\
\hline \multirow[t]{13}{*}{ Hexanic } & - & $112 \pm 4.2$ & 4.2 & $193.2 \pm 5.6$ & 2.4 & $472.3 \pm 1.2$ \\
\hline & 1 & $>250$ & ND & $>250$ & ND & $>250$ \\
\hline & 2 & $>250$ & ND & $>250$ & ND & $>250$ \\
\hline & 3 & $>250$ & ND & $>250$ & ND & $>250$ \\
\hline & 4 & $213.5 \pm 0.7$ & $>1.1$ & $83.8 \pm 1.8$ & $>3$ & $>250$ \\
\hline & 5 & $>250$ & ND & $225.3 \pm 0.4$ & $>1.1$ & $>250$ \\
\hline & 6 & $224.5 \pm 2.8$ & $>1.1$ & $199.9 \pm 0.9$ & $>1.3$ & $>250$ \\
\hline & 7 & $182.2 \pm 0.2$ & $>1.4$ & $244.5 \pm 2.1$ & ND & $>250$ \\
\hline & 8 & $98.2 \pm 0.2$ & $>2.5$ & $249.4 \pm 0.9$ & ND & $>250$ \\
\hline & 9 & $>250$ & ND & $115.7 \pm 0.2$ & $>2.1$ & $>250$ \\
\hline & 10 & $246.2 \pm 0.2$ & ND & $>250$ & ND & $>250$ \\
\hline & 11 & $22.6 \pm 0.3$ & $>11.4$ & $12.3 \pm 0.8$ & $>20.3$ & $>250$ \\
\hline & 12 & $42.9 \pm 0.1$ & $>5.8$ & $7.8 \pm 1.3$ & $>32$ & $>250$ \\
\hline Ethanolic & - & $144.5 \pm 4.9$ & 2.5 & $>500$ & $<0.7$ & $366.5 \pm 6.4$ \\
\hline 13E-docosenamide & - & - & - & $9.6 \pm 1.4$ & $>10.4$ & $>100$ \\
\hline Amphotericin B & - & $1.5 \pm 0.1$ & 4.7 & $5.3 \pm 0.7$ & 1.3 & $7.1 \pm 0.3$ \\
\hline
\end{tabular}

Experiments were carried out in two independent replicates. Results are expressed in mean \pm standard deviation. $\mathrm{ND}=$ not determined. 


\section{RESULTS AND DISCUSSION}

Herein, we explored for the first time the antileishmanial activity of the Antarctic alga $H$. grandifolius. For this, hexane and ethanol extracts were obtained and analyzed regarding their potential antileishmanial and cytotoxic activities. Both ethanolic and hexanic extracts exhibited a mild anti- $L$. amazonensis promastigote effect $\left(\mathrm{IC}_{50}=112.0\right.$ and $144.5 \mu \mathrm{g} \mathrm{ml}^{-1}$, resp. $)$ and were at least two times more selective to the parasite rather than to the host cells (SI $>4.2$ and 2.5, resp.); however, only the hexanic extract was able to maintain the leishmanicidal activity against amastigotes $\left(\mathrm{IC}_{50}\right.$ $=193.1 \mu \mathrm{g} \mathrm{ml}^{-1}$ ) (Table 1). Following a bio-guided fractionation approach, chromatographic analysis of the bioactive hexane extract was carried out, indicating that most of the compounds are present in a retention time region between 10 and 22 minutes (Figure 1). Thus, the fractionation of this hexane extract produced 12 fractions (HGS) that were further investigated regarding the maintenance of their antileishmanial activity. The fractions HGS4-9 and HGS1112 showed varied antiamastigote activity from 7 to $250 \mu \mathrm{g} \mathrm{ml}{ }^{-1}$ (Table 1). Among them, the most potent fractions HGS11 $\left(\mathrm{IC}_{50}=\right.$ $12.3 \mu \mathrm{g} \mathrm{ml}^{-1}$; SI > 9.3) and HGS12 $\left(\mathrm{IC}_{50}=7.8 \mu \mathrm{g} \mathrm{ml}^{-1}\right.$; SI > 5.1) showed a similar range of activity when compared to amphotericin $\mathrm{B}\left(\mathrm{IC}_{50}=5.3 \mu \mathrm{g} \mathrm{ml}^{-1} ; \mathrm{SI}=1.3\right)$ and so the chemical nature was putatively determined.

Since both HGS11 and HGS12 were collected in a short time frame of only one millisecond apart, it is not possible to rule out that HGS11 might contain part of 13E-docosenamide from HGS12, which would suggest the presence of this fatty acid in both subfractions. Besides, the intensity of 13E-docosenamide in HGS12 is nearly 10 times higher than HGS11, which might explain why
HGS12 $\left(\mathrm{IC}_{50}=7.8 \mu \mathrm{g} \mathrm{ml}^{-1}\right)$ is almost twice as active as $\mathrm{HGS} 11\left(\mathrm{IC}_{50}\right.$ $\left.=12.3 \mu \mathrm{g} \mathrm{ml}^{-1}\right)$. Moreover, among the other compounds present in HGS12, the 3-ethyl-5-methoxy-N-\{4-[4-(2-methylphenyl)-1piperidinyl]cyclohexyl $\}$-1H-indole-2-carboxamide (Table 2S) was

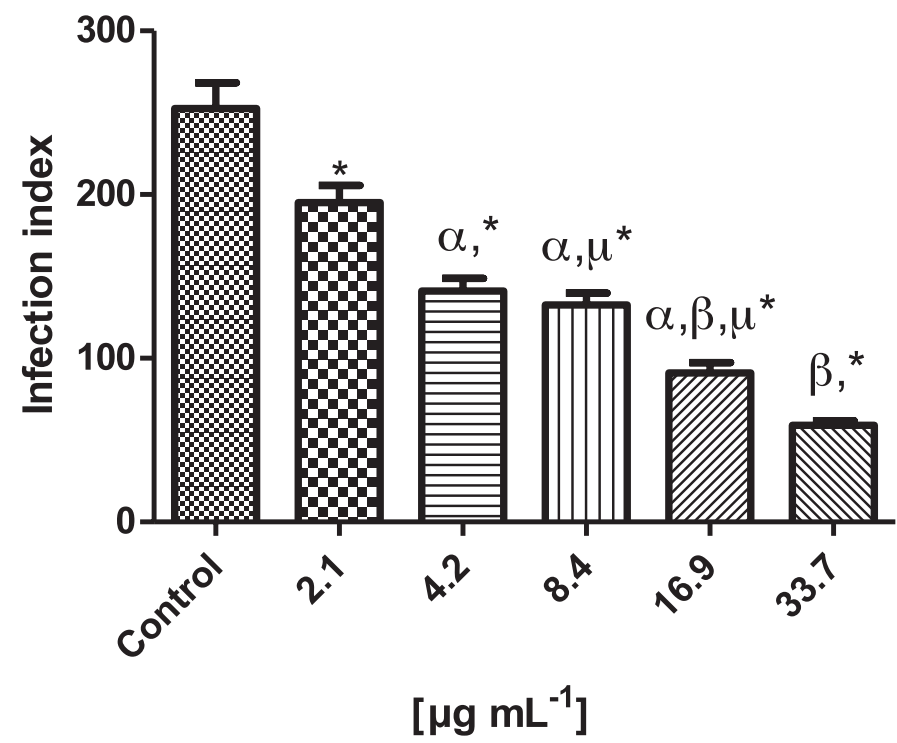

Figure 2. Infection rate (number of the intracellular parasites/number of infected cells) of peritoneal macrophages infected with L. amazonensis and treated with 13 E-docosenamide. Data expressed as mean \pm standard deviation. *Statistically significant for each group compared to the negative control $(p<0.05) . \alpha, \beta$, and $\mu$ : nonsignificant.
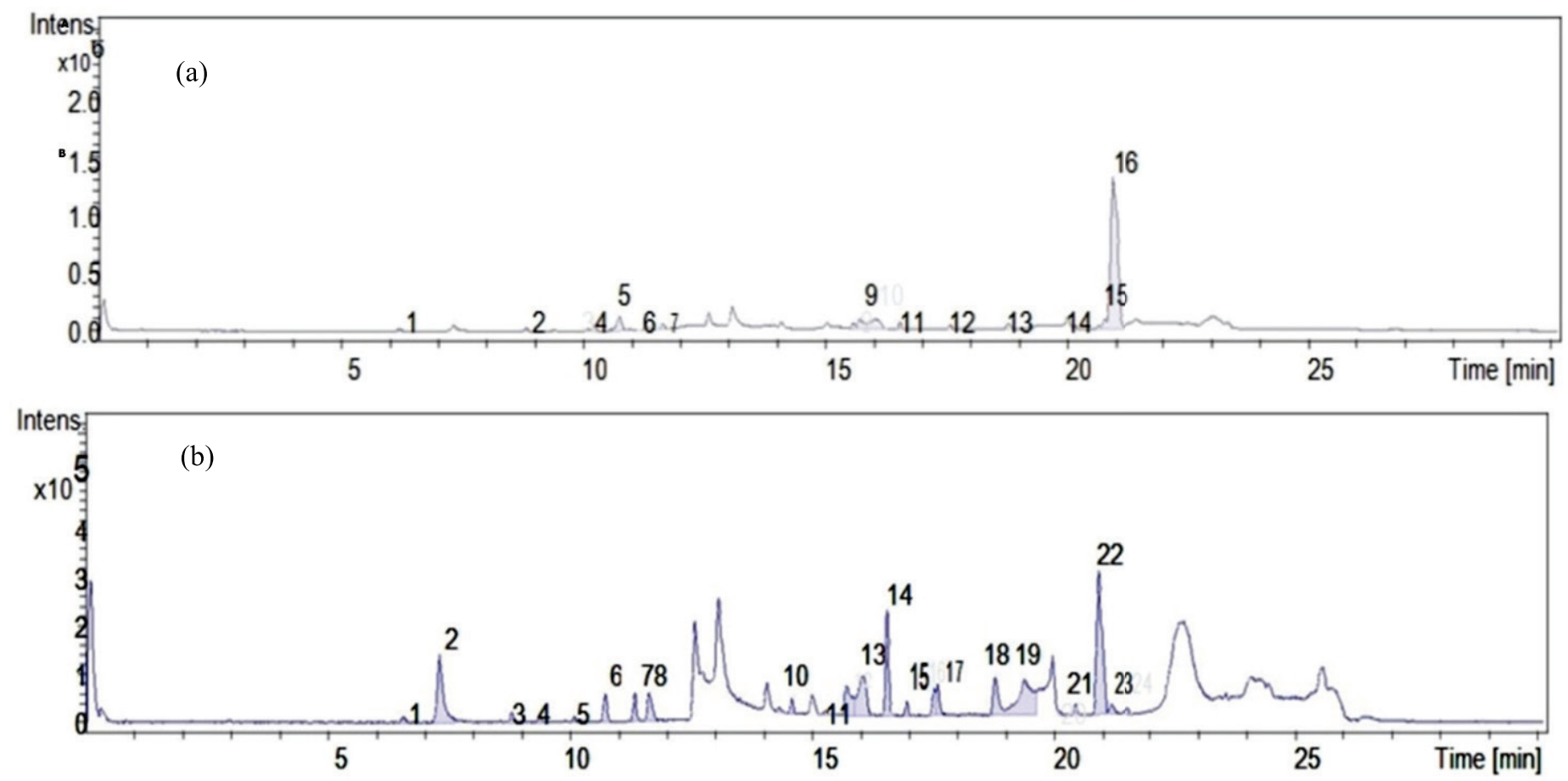

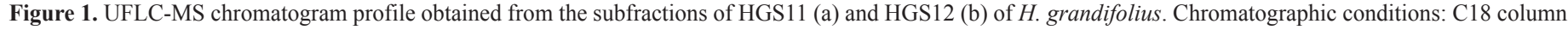

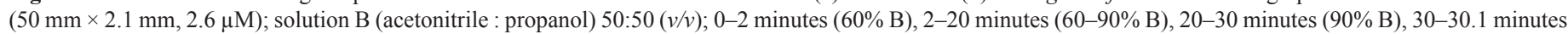
$(60 \% \mathrm{~B}), 30.1-40$ minutes $(60 \% \mathrm{~B})$; flow rate $1 \mathrm{ml} /$ minute. 


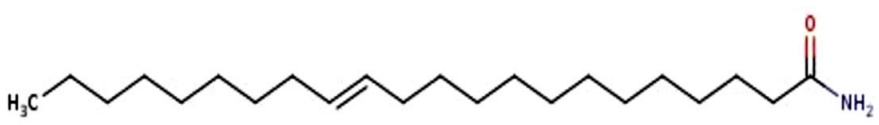

Figure 3. Chemical structure of fatty acid 13E-docosenamide.

previously characterized as an anti-Plasmodium falciparum agent (Gamo et al., 2010), suggesting that $H$. grandifolius is a rich source of other natural products that can be explored for the development of new drugs to treat other infectious diseases.

The hypothesis that 13E-docosenamide is the antileishmanial component of the $H$. grandifolius fraction HGS12 was tested against $L$. amazonensis amastigotes using the pure fatty acid (98\% purity) purchased from Sigma. As expected, the fatty acid presented activity $\left(\mathrm{IC}_{50}=9.6 \mu \mathrm{g} \mathrm{ml}^{-1}\right)$ against intracellular amastigotes and was 10 times more selective to the parasite rather than to the host cells (SI > 10.4). A dose-dependent response to treatment with 13E-docosenaminde was found, and the infection index was $195-2.1,141-4.1,132.5-8.2,91-16.9$, and 59-33.7 $\mu \mathrm{g} \mathrm{ml}^{-1}$ (Figure 2). Although 13E-docosenamide was twofold less active than amphotericin $\mathrm{B}\left(\mathrm{IC}_{50}=5.3 \mu \mathrm{g} \mathrm{ml}^{-1}\right)$, it is more selective (SI > 10.4), almost 10 times superior to that obtained for amphotericin B $(\mathrm{SI}=1.2)$.

Besides the large use of marine macroalgae as food and source of polyunsaturated fatty acids (omega 3 and 6) and steroids (Pereira et al., 2017; Santos et al., 2017), they are also well known as an important source of bioactive natural products, which have been explored for the discovery of new therapeutic agents (Martins et al., 2018; Pacheco et al., 2018) or as starting material for the synthesis of known drugs (Cardozo et al., 2007; Gressler et al., 2011). Indeed, these organisms feature several new chemicals, showing biological effects such as antitumor, anti-inflammatory, analgesic, immunomodulatory, antiallergic, antiviral, and antiparasitic activities (Blunt et al., 2010; Mayer et al., 2013; Newman and Cragg, 2016). Flavonoids, chalcones, lignans, coumarins, iridoids, monoterpenes, saponins, curcumin, quinoline alkaloids, and polyketides are among the natural products from marine sources that exhibit antileishmanial properties (Falkenberg et al., 2019).

The chemical profile showed that peak 15 from HGS11 (Table 1S) matches the triterpeneroxburghiadiol B previously characterized as anti-inflammatory, antiviral, and anticancer agents (Janaki et al., 1999). Indeed, other triterpenes isolated from the terrestrial plant Maytenus ilicifolia, maytenin and pristimerin, also show antileishmanial activity (Dos Santos et al., 2013). In addition, this same peak may also contain the marine metabolite 25-hydroxysarcosterol, a sterol with unknown bioactivity, which was first isolated from the coral species Sarcophyton glaucum and Sinularia mayi (Kobayashi, 1994; Wang et al., 2013). Another interesting data refers to the peaks 16 from HSG11 (Figure 1S) and 22 from HSG12 (Figure $2 \mathrm{~S}$ ), both corresponding to the fatty acid 13E-docosenamide (Figure 3), already described as a chemical constituent of the dinoflagellate microalgae Symbiodinium spp. and previously explored regarding its potential antibacterial and antifungal properties (dos Reis et al., 2019; Garg et al., 2018; Parkinson and Baums, 2014; Pradheesh, 2017; Zhang et al., 2018).

The great advantage of seaweeds in drug discovery is not only their enormous diversity of secondary metabolites presenting different bioactivities (Falkenberg et al., 2019), but also the possibility of their large-scale cultivation (de Oliveira Fernandes et al., 2017; Huang and Rorrer 2002; Rorrer et al., 1995) and utilizing green extraction technologies to obtain the desired secondary metabolites, as well as other bioproducts with biotechnological potential (Górka and Wieczorek 2017; Ospina et al., 2017; Prieto-Sandoval et al., 2018).

\section{CONCLUSION}

This study reveals that the antileishmanial potential of Antarctic alga $H$. grandifolius and the effect of the compound 13E-docosenamide against $L$. amazonensis amastigotes, the most important form involved in disease development, indicate its great potential for the next steps on drug discovery in the treatment of cutaneous leishmaniasis.

\section{ACKNOWLEDGMENTS}

The authors are grateful to FAPESP, Grants nos. 2013/08248-1 and 2016/06931, and CNPq-Ministério da Defesa, Grant no. 407588/2013-2, for financial support and CAPES for providing scholarships.

\section{CONFLICT OF INTEREST}

The authors declared that there are no conflicts of interest associated with this work.

\section{APPENDIX A}

Supplementary data: HGS11 and HGS12 MS and metabolites analysis datasheets.

\section{REFERENCES}

Blunt JW, Copp BR, Munro MHG, Northcote PT, Prinsep MR. Marine natural products. Nat Prod Rep, 2010; 27:165-237.

Cardozo KHM, Guaratini T, Barros MP, Falcão VR, Tonon AP, Lopes NP, Campos S, Torres MA, Souza AO, Colepicolo P, Pinto E. Metabolites from algae with economical impact. Comp Biochem Physiol, $2017 ; 146: 60-78$.

Clementino LC, Velásquez AMA, Passalacqua TG, de Almeida L, Graminha MAS, Martins G, Salgueiro L, Cavaleiro C, Sousa MC, Moreira RRD. In vitro activities of glycoalkaloids from the Solanum lycocarpum against Leishmania infantum. Braz J Pharmacogn, 2018; 28(6):673-7.

de Oliveira Fernandes F, de Oliveira SR, Klein V, Carneiro MAA, Colepicolo P, Soriano EM. Effect of fertilization pulses on the production of Gracilaria birdiae seedlings under laboratory and field conditions. J Appl Phycol, 2017; 29:695-705.

Dieckmann G, Reichardt W, Zielinski K. Growth and production of the seaweed, Himantothallus grandifolius at King George Island. In: Siegfried WR, Condy PR, Laws RM (eds.). Antarctic nutrient cycles and food webs. Springer, Berlin, Heidelberg, 1985.

dos Reis CM, da Rosa BV, da Rosa GP, do Carmo G, Morandini LMB, Ugalde GA, Kuhn KR, Morel AF, Jahn SL, Kuhn RC. Antifungal and antibacterial activity of extracts produced from Diaporthe schini. J Biotechnol, 2019; 294:30-7. 
Dos Santos VAFFM, Leite KM, da Costa SM, Regasini LO, Martinez I, Nogueira CT, Galuppo MK, Stolf BS, Pereira AMS, Cicarelli RMB, Graminha MAS. Antiprotozoal activity of quinonemethide triterpenes from Maytenus ilicifolia (Celastraceae). Molecules, 2013; 18:1053-62.

Drew EA, Hastings RM. A year-round ecophysiological study of Himantothallus grandifolius (Desmarestiales, Phaeophyta) at Signy Island, Antarctica. Phycologia, 1992; 31:267-77.

Falkenberg M, Nakano E, Zambotti-Villela L, Zatelli GA, Philippus AC, Imamura KB, Velásquez AMA, Freitas RP, Tallarico LF, Colepicolo P, Graminha MAS. Bioactive compounds against neglected diseases isolated from macroalgae: a review. J Appl Phycol, 2019; 31:797-823.

Gambato G, Baroni EDG, Garcia CSC, Frassini R, Frozza CO, Moura S, Pereira CMP, Fujii MT, Colepicolo P, Lambert AP, Henriques JAP, Roesch-Ely M. Brown algae Himantothallus grandifolius (Desmerestiales, Phaeophyceae) suppresses proliferation and promotes apoptosis-mediated cell death in tumor cells. Adv Biol Chem, 2014; 4:98-108.

Gamo FJ, Sanz LM, Vidal J, de Cozar C, Alvarez E, Lavandera JL, Vanderwall DE, Green DVS, Kumar V, Hasan S, Brown JR, Peishoff CE, Cardon LR, Garcia-Bustos JF. Thousands of chemical starting points for antimalarial lead identification. Nature, 2010; 465:305-10.

Garg M, Priyanka, Chatterjee M. Isolation, characterization and antibacterial effect of biosurfactant from Candida parapsilosis. Biotechnol Rep, 2018; 18:e00251.

Górka B, Wieczorek PP. Simultaneous determination of nine phytohormones in seaweed and algae extracts by HPLC-PDA. J Chromatogr B Anal Technol Biomed Life Sci, 2017; 1057:32-9.

Gressler V, Fujii MT, Martins AP, Colepicolo P, Mancini-Filho J, Pinto E. Biochemical composition of two red seaweed species grown on the Brazilian coast. J Sci Food Agric, 2011; 91:1687-92.

Huang YM, Rorrer GL. Optimal temperature and photoperiod for the cultivation of agardhiella subulata microplantlets in a bubble-column photobioreactor. Biotechnol Bioeng, 2002; 79:135-44.

Iken K, Amsler CD, Hubbard JM, McClintock JB, Baker BJ. Allocation patterns of phlorotannins in Antarctic brown algae. Phycologia, $2017 ; 46: 386-95$.

Janaki S, Vijayasekaran V, Viswanathan S, Balakrishna K. Antiinflammatory activity of Aglaia roxburghiana var. beddomei extract and triterpenes roxburghiadiol A and B. J Ethnopharmacol, 1999; 67:45-51.

Kobayashi M. Marine sterols. 27. 25-hydroxy derivative of sarcosterol, a novel marine sterol with a 23-methyl and a 17(20)E-double bond, from the soft coral Sinularia mayi. Steroids, 1994; 59:27-9.

Martins RM, Nedel F, Guimarães VBS, da Silva AF, Colepicolo P, Pereira CMP, Lund RG. Macroalgae extracts from Antarctica have antimicrobial and anticancer potential. Front Microbiol, 2018; 9:412.

Mayer AMS, Rodríguez AD, Taglialatela-Scafati O, Fusetani N. Marine pharmacology in 2009-2011: marine compounds with antibacterial, antidiabetic, antifungal, anti-inflammatory, antiprotozoal, antituberculosis, and antiviral activities; affecting the immune and nervous systems, and other miscellaneous mechanisms of. Mar Drugs, $2013 ; 11: 2510-73$.

Molyneux DH, Savioli L, Engels D. Neglected tropical diseases: progress towards addressing the chronic pandemic. Lancet, 2016; 389:312-25.

Newman DJ, Cragg GM. Natural products as sources of new drugs from 1981 to 2014. J Nat Prod, 2016; 79:629-61.

Ospina M, Castro-Vargas HI, Parada-Alfonso F. Antioxidant capacity of Colombian seaweeds: 1. extracts obtained from Gracilaria mammillaris by means of supercritical fluid extraction. J Supercrit Fluids, 2017; 128:314-22.

Pacheco BS, dos Santos MAZ, Schultze E, Martins RM, Lund RG, Seixas FK, Colepicolo P, Collares T, Paula FR, de Pereira CMP.
Cytotoxic activity of fatty acids from Antarctic macroalgae on the growth of human breast cancer cells. Front Bioeng Biotechnol, 2018; 6:185. doi: 10.3389/fbioe.2018.00185

Parkinson JE, Baums IB. The extended phenotypes of marine symbioses: ecological and evolutionary consequences of intraspecific genetic diversity in coral-algal associations. Front Microbiol, 2014; 25:445. doi: 10.3389/fmicb.2014.00445.

Pereira CMP, Nunes CFP, Zambotti-Villela L, Streit NM, Dias D, Pinto E, Gomes CB, Colepicolo P. Extraction of sterols in brown macroalgae from Antarctica and their identification by liquid chromatography coupled with tandem mass spectrometry. J Appl Phycol, 2017; 29:751-7.

Pereira H, Barreira L, Figueiredo F, Custódio L, VizettoDUarte C, Polo C, Resek E, Engelen A, Varela J. Polyunsaturated fatty acids of marine macroalgae: potential for nutritional and pharmaceutical applications. Mar Drugs, 2012; 10:1920-35.

Pradheesh G, Suresh J, Suresh S, Alexramani V. Antimicrobial activity and identification of potential ethanolic antimicrobial compounds from the medicinal plant Pisonia grandis $r$.Br. World J Pharm Pharm Sci, 2017; 6:1686-700.

Prieto-Sandoval V, Jaca C, Ormazabal M. Towards a consensus on the circular economy. J Clean Prod, 2018; 179: 605-15.

Punín Crespo MO, Lage Yusty MA. Comparison of supercritical fluid extraction and Soxhlet extraction for the determination of aliphatic hydrocarbons in seaweed samples. Ecotoxicol Environ Saf, 2006; 64:400-5.

Rorrer GL, Modrell J, Zhi C, Yoo HD, Nagle DN, Gerwick WH. Bioreactor seaweed cell culture for production of bioactive oxylipins. J Appl Phycol, 1995; 7:187-98.

Santos MAZ, Colepicolo P, Pupo D, Jufii MT, Pereira CMP, Mesko MF. Antarctic red macroalgae: a source of polyunsaturated fatty acids. J Appl Phycol, 2017; 29:759-67.

Sundar S, Chakravarty J. An update on pharmacotherapy for leishmaniasis. Expert Opin Pharmacother, 2015; 16:237-52.

Torres FAE, Passalacqua TG, Velásquez AMA, de Souza RA, Colepicolo P, Graminha MAS. New drugs with antiprotozoal activity from marine algae: a review. Rev Bras Farmacogn, 2014; 24:265-76.

Velásquez AMA, De Souza RA, Passalacqua TG, Ribeiro AR, Scontri M, CHin CM, de Almeida L, Del Cistia M, da Rosa JA, Mauro AE, Graminha MASD. Antiprotozoal activity of the cyclopalladated complexes against Leishmania amazonensis and trypanosoma cruzi. J Braz Chem Soc, 2016; 27:1032-9.

Wang Z, Tang H, Wang P, Gong W, Xue M, Zhang H, Liu T, Liu B, Yi Y, Zhang W. Bioactive polyoxygenated steroids from the South China Sea soft coral, Sarcophyton sp. Mar Drugs, 2013; 11:775-87.

Zhang S, Xu B, Zhang J, Gan Y. Identification of the antifungal activity of Trichoderma longibrachiatum T6 and assessment of bioactive substances in controlling phytopathgens. Pestic Biochem Physiol, 2018; 147:59-66.

How to cite this article:

Clementino LC, Torres FAE, Velasquez AMA, Villela L, Mutue TF, Colepicolo P, Graminha MAS. Bioguided study of the Antarctic alga Himantothallus grandifolius (A. Geep \& E.S.Geep) indicates 13E-Docosenamide as potential antileishmanial agent. J Appl Pharm Sci, 2020; 10(12):098-103. 